\title{
PRETREATMENT OF COMPLEX INDUSTRIAL WASTEWATER BY OZONATION
}

\author{
Muhammad Saif Ur Rehman*, Nasir Ahmad, Muhammad Sarwar and Waqas Hussain
}

Wastewater Research Laboratory, Institute of Geology, University of the Punjab, Lahore 54590-Pakistan

Tel \# 92-321-4053698, Fax \# 92-42-5121658

(Email: msrzia@gmail.com, envrnet@brain.net.pk,msarwarkasuri@gmail.com and waqasctn@gmail.com)

* Corresponding Author

\begin{abstract}
Wastewater generated by various processing industries resists conventional wastewater treatment due to its complexity and recalcitrant nature. Ozone is a potential oxidant and is used for various types of wastewater treatment applications. Ozone forms no additional sludge, and aids in the removal of color and chemical oxygen demand (COD). The aim of this work is to investigate ozone application as a pretreatment technique for complex industrial wastewater of Hudiara drain and find an appropriate choice of reaction conditions like ozonation time, $\mathrm{pH}$ and temperature necessary to increase ozonation process efficiency. Ozone process efficiency is measured in terms of color and COD removal. Results show that increased ozonation time results in increased color and COD removal due to enhanced mass transfer. A 20-minute ozonation time appears to be optimal for further application. Alkaline $\mathrm{pH}$ shows significant effect on the ozonation process. A pH value of 9 is optimal reducing color up to $82 \%$ and COD to $67 \%$ but the effect of temperature is immaterial. Ozonation process followed pseudo-first order reaction kinetics for color and COD removal.
\end{abstract}

Key Words: Color, COD, Ozonation

\section{Introduction}

Over the past few decades, environmental regulatory requirements have become more stringent because of increased awareness of the human health and ecological risks associated with environmental contaminants. Industrial wastewater from different processing industries contains toxic chemicals which may lead to reduction in the number of aquatic species or complete destruction of aquatic life in extreme cases. Some chemicals also bioaccumulate, i.e. they become more concentrated as they move up the food chain, posing toxicity problems even at very low concentrations. The effects of some of the chemicals on human health include increased risk of cancer, neurological or reproductive effects and even mortality.

Complex industrial wastewater from different processing industries like textile, pulp and paper, leather and metal processing industries is a main source of surface water pollution. 
Beside strong color and COD, this wastewater is characterized by a high content of surfactants, various auxiliary agents and strong mineralization (mainly chloride and carbonate). Despite the relatively small content of colorants in wastewater, their variety and stability hamper or even prevent their treatment. The treatment of complex industrial wastewater is a difficult and costly task because of its quantity and composition.

Conventional physico-chemical wastewater treatment technologies such as flocculation (Buschmann and Schollmeyer, 1997), sorption (Juang et al. 1997) and electrochemical degradation (Nansheng et al. 1997; Salem, 2000) are limited by their performance. These treatment technologies merely transfer wastewater pollutants from one medium to another and problems of sludge disposal and environmental persistence even remain. On the other hand, industrial wastewater is not generally amenable to conventional biological treatment methods (Correia et al. 1994) due to its recalcitrant and complex nature. This situation demands selection of an appropriate treatment method for such wastewater.

Chemical oxidative pretreatment presents an alternative solution for treating recalcitrant wastewater by converting refractory compounds to more biodegradable by-products that are treatable through a downstream biological process. Chemical oxidation with ozone presents desirable properties for wastewater treatment. Ozone is a powerful oxidant, soluble in water and readily available. Ozone is very reactive towards compounds incorporating conjugated double bonds, often associated with color, and functional groups with high electron densities. In general, it has been stated that ozone cleaves the conjugated bonds of dye molecule, which results in color removal. The cleavage of dye bonds takes place in ozonation process by both direct ozonation and radical pathways as explained in literature (Sevimli and Sarikaya, 2002). Despite being a promising technology for decoloring industrial effluents, few studies concerning the degradation of effluents from industries by ozonation are available (Alfafara et al. 2000). Ozone can also be applied as a process integration technique either before or after the biological treatment process. Preozonation may be expected to ease biological treatment by converting more slowly biodegradable COD into simpler compounds or by reducing the amount of inert organic matter.

To reduce the costs associated with the use of ozone as pretreatment technique for complex industrial wastewater, efficiency of the process has to be optimized. An appropriate choice of the reaction conditions is necessary to increase the ozonation efficiency. The aim of this work is to optimize operating conditions such as ozonation time, $\mathrm{pH}$ and temperature in terms of color and COD removal. The effect of these variables on ozonation efficiency is studied along with reaction kinetics in order to gain understanding regarding the influence of these parameters on the ozonation process.

\section{Methods}

\section{Wastewater characterization}


Integrated wastewater samples have been taken from Hudiara drain and characterized in terms of $\mathrm{pH}$, color, COD and total dissolved solids (TDS) according to the methods given in Standard Methods for the Examination of Water and Wastewater (APHA, 1998). The characteristics of wastewater are listed in Table 1.

Table 1: Characteristics of complex industrial wastewater

\begin{tabular}{llc}
\hline Parameter & Unit & Wastewater \\
\hline $\mathrm{pH}$ & & 7.9 \\
Color & absorbance at 465nm & 0.92 \\
$\mathrm{COD}$ & $\mathrm{mg} / \mathrm{l}$ & 540 \\
$\mathrm{TDS}$ & $\mathrm{mg} / \mathrm{l}$ & 971 \\
\hline
\end{tabular}

\section{Ozonation process}

Ozonation is carried out in a bubble column reactor made of Perspex with internal diameter of $3.3 \mathrm{~cm}$. A JQ-6M PURETECH model ozone generator with a capacity to produce gas at the rate of $1.1 \mathrm{1} / \mathrm{min}$ is employed. The gas is fed to reactor through diffusing stone. Ozonation time is varied from 5 to 25 minutes. In order to assess the influence of $\mathrm{pH}$ on ozonation process, $\mathrm{pH}$ is varied from 7 to 11 using $\mathrm{NaOH}$ and $\mathrm{H}_{2} \mathrm{SO}_{4}$. Temperature is varied from 25 to $70{ }^{\circ} \mathrm{C}$ using a hot plate. Ozone treated effluent is sampled at regular time intervals for the determination of color and COD reduction.

\section{Kinetic assessment of ozonation process}

Industrial wastewater is very complex due to organic chemicals such as many different dyes, carriers, biocides, bleaching agents, complexation agents, ionic and non-ionic surfactants, sizing agents, etc. As a result, it is hard to explain the overall degradation of organic matter by ozone in case of complex wastewater. Thus, some global wastewater parameters such as color and COD are used for degradation kinetics of organic matter by ozonation (Staehelin, and Hoigne, 1985). A first order kinetic reaction described by equation 1 and 2 has been extensively used in the literature to fit degradation kinetics of various organic compounds in wastewater.

$-\ln \left(\mathrm{A} / \mathrm{A}_{\mathrm{o}}\right)=\mathrm{k}_{\mathrm{d}} \mathrm{t}$

$-\ln \left(\mathrm{C} / \mathrm{C}_{\mathrm{o}}\right)=\mathrm{k}_{\mathrm{cod}} \mathrm{t}$

From the equations listed, $\mathrm{k}_{\mathrm{d}}$ is decolorization pseudo-first order rate constant while $\mathrm{k}_{\text {cod }}$ is degradation pseudo-first order rate constant, $t$ is the ozone feed time, $\mathrm{A}$ is the absorbance at time $\mathrm{t}$ while $\mathrm{A}_{\mathrm{o}}$ is absorbance at $\mathrm{t}=0$, similarly, $\mathrm{C}$ is $\mathrm{COD}$ at a given time while $\mathrm{C}_{\mathrm{o}}$ is $\mathrm{COD}$ at $\mathrm{t}=0$.

Using equations 1 and $2, \mathrm{k}_{\mathrm{d}}$ and $\mathrm{k}_{\mathrm{cod}}$ can be calculated.

$$
\begin{aligned}
& \mathrm{k}_{\mathrm{d}}=-\ln \left(\mathrm{A} / \mathrm{A}_{\mathrm{o}}\right) / \mathrm{t} \\
& \mathrm{k}_{\mathrm{cod}}=-\ln \left(\mathrm{C} / \mathrm{C}_{\mathrm{o}}\right) / \mathrm{t}
\end{aligned}
$$

\section{Results and Discussion}


It is evident from Figure 1a that ozonation time has significant impact on color and COD removal. Both color and COD removal increase continuously with increasing ozonation time up to 20 minutes beyond which no appreciable removal appears. An increase in ozonation time enhances the mass transfer, which results to increased ozone content in liquid phase and enhanced degradation rate constant (Wu and Wang, 2001). However, removal efficiency increases insignificantly when ozone concentration in the liquid phase approaches its maximum value. This is because the process is increasingly controlled by the rate of chemical reaction and any further improvement in ozone mass transfer would have a diminished effect on the observed reaction rate ( $\mathrm{Wu}$ et al. 1998). Overall COD removal is low compared with color removal, which can be attributed to the fact that ozonation process becomes less efficient because of the increased competition for ozone between parent molecules and the reaction by-products (Sevimli and Kianaci, 2002). Figure 1a demonstrates that 20 minutes of ozonation time appears to be optimal in terms of color and COD reduction.

It is apparent from Figure $1 \mathrm{~b}$ that decolorization and COD reduction follow pseudo first order kinetics. Increased ozonation time enhances decolorization rate due to increased mass transfer (Wu et al. 1998; Pena et al. 2003)

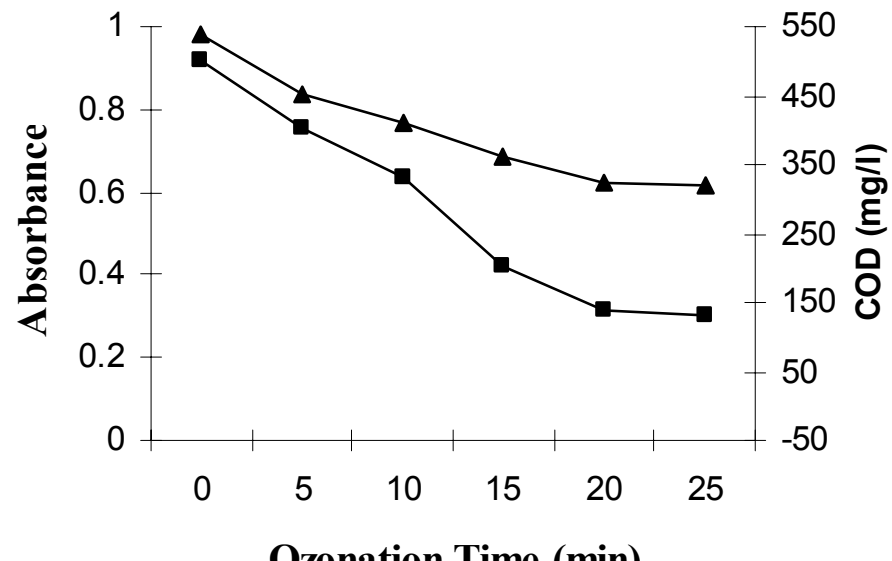

$$
\rightarrow-\text { Color } ₫ \text { COD }
$$

Figure 1a: Effect of ozonation time on color and COD removal of wastewater 


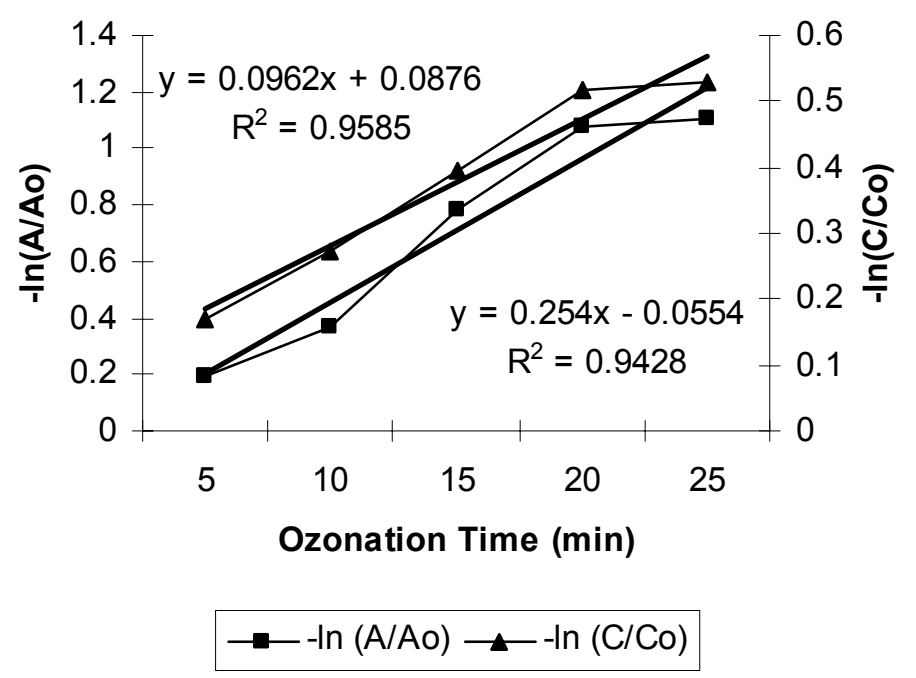

Figure 1b: Effect of ozonation time on color and COD removal rates

Reaction $\mathrm{pH}$ is an important parameter, which has significant influence on the performance of ozonation process (Sevimli and Kianaci, 2002; Glaze et al. 1987). At low $\mathrm{pH}$, ozone reacts with specific functional groups through selective direct reactions. At high $\mathrm{pH}$ however, the hydroxide ions catalyze the decomposition of ozone to yield highly reactive and non-selective hydroxyl radicals, which have oxidation potentials higher than that of ozone. An optimal color reduction of 83 percent $(\mathrm{A}=0.17)$ and $\mathrm{COD}$ removal of 68 percent $(\mathrm{COD}=178 \mathrm{mg} / \mathrm{l})$ at $\mathrm{pH} 9$ were evident for an ozone exposure of 20 minutes as shown in Figure 2a, which can be attributed to the maximum generation of hydroxyl radicals at this $\mathrm{pH}$ (Shu and Huang, 1995; Wu and Wang, 2001). However, a prominent decrease in color and COD removal after $\mathrm{pH} 9$ was also observed. Color reduction can be explained by the fact that dye molecules with greater affinity towards ozone are selectively oxidized in preference to other dyes in the solution thereby increasing the recalcitrant fraction of the waste stream which remains untreated and is responsible for decrease in color removal (Saunders et al., 1983; Qian et al., 1994) on the other hand, decreased COD removal is because ozone first converts suspended solids into dissolved solids but subsequent ozonation destructs high suspended solids into very small molecules which increase COD level in the ozonated wastewater (Ramasamy et al. 2003).

Elevated $\mathrm{pH}$ has a positive impact on decolorization and $\mathrm{COD}$ reduction rate constants. Radical reactions increase with increasing $\mathrm{pH}$ value. Both $\mathrm{K}_{\mathrm{d}}$ and $\mathrm{K}_{\text {cod }}$ increase until $\mathrm{pH} 9$ and then decrease (Figure 2b). Reactions between ozone and substrate at alkaline $\mathrm{pH}$ occur by means of hydroxyl radicals, which are very reactive, compared to molecular ozone and show high decolorization rates. However, at elevated $\mathrm{pH}(>9)$, the removal rates of color and COD decrease and is due to the fact that any beneficial increase in reaction rate is counteracted by the greater ozone requirement due to loss of oxidant caused by increased self-decomposition (Gilbert, 1982). 


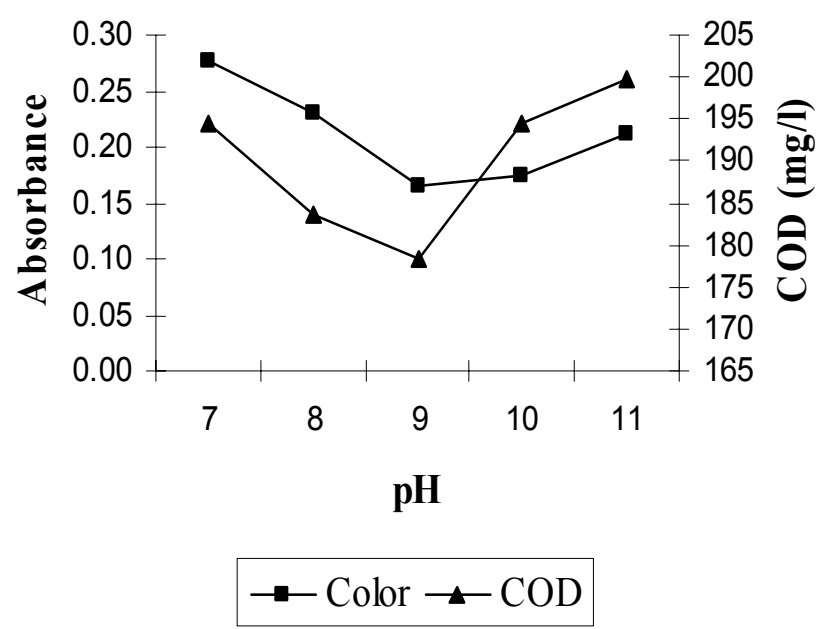

Figure 2a: Effect of pH on the ozonation process efficiency

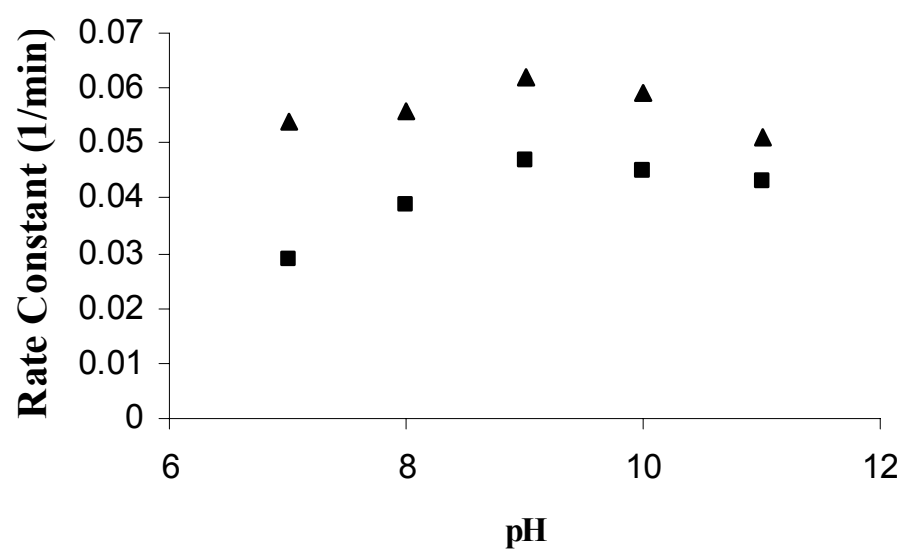

\ $\operatorname{Kd}(1 / \mathrm{min}) \cdot \operatorname{Kcod}(1 / \mathrm{min})$

Figure 2b: Effect of pH on reaction rate constant

Temperature has shown insignificant effect on the efficiency of ozone. Results (Figure 3a and b) show that both color and COD removal rates decrease continuously with the increase in temperature for an optimized ozonation time of 20 minutes .This decrease in removal rate may be due to the decrease in ozone solubility thereby reducing the amount of ozone available for the reaction, resulting to decreased degradation rates (Beltran et al. 1994). 


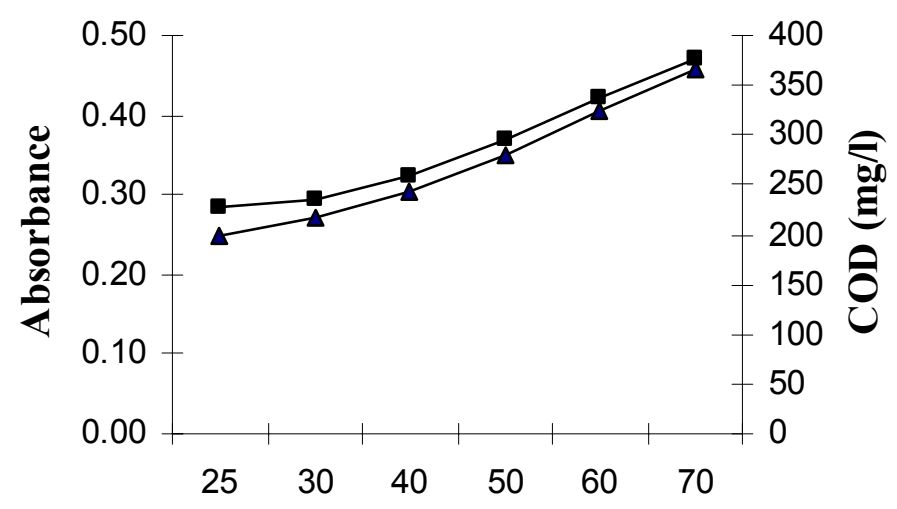

Temperature (C)

$\rightarrow-$ Color $\rightarrow$ COD

Figure 3a: Effect of temperature on ozonation of complex wastewater

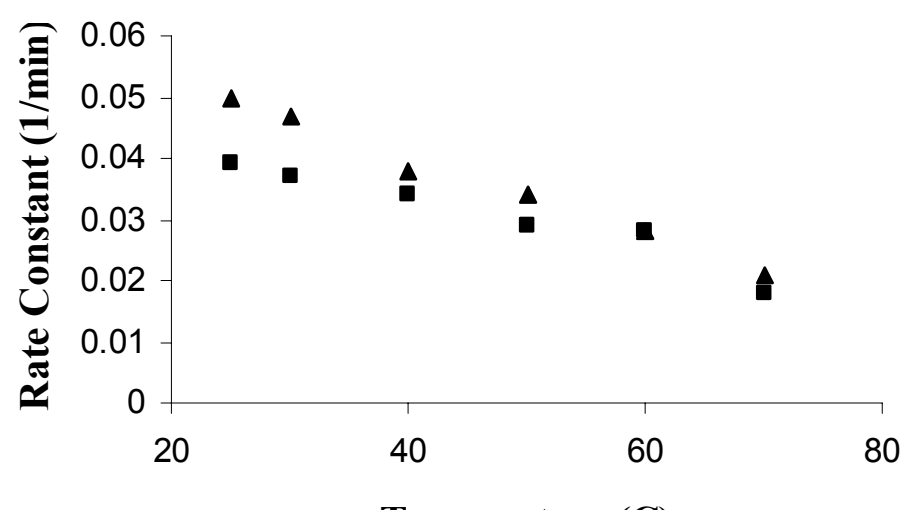

Temperature (C)

$$
\Delta \mathrm{Kd} \cdot \mathrm{Kcod}
$$

Figure 3b: Effect of temperature on reaction rate constants

\section{Conclusions}

In this study, complex industrial wastewater taken from Hudiara drain which comprises textile, pulp and paper, metal processing and leather industries has been treated by ozone in order to determine the effect of ozonation time, $\mathrm{pH}$ and temperature on color and COD removal. Kinetic evaluation has been performed for all circumstances.

Based on the experimental results, the following conclusions were drawn.

- Increased ozonation time increases color and COD removal rates through enhanced mass transfer.

- $\mathrm{pH}$ has an impact on ozone efficiency. $\mathrm{pH} 9$ proves to be optimal resulting to 82 percent color removal and 68 percent COD removal. However, beyond this $\mathrm{pH}$, a 
significant decrease in color and COD reduction has been observed due to the loss of oxidant caused by increased self decomposition.

- Effect of temperature on ozone process efficiency is insignificant due to the low solubility of ozone at elevated temperatures.

- Ozonation process followed pseudo-first order reaction kinetics in terms of color and COD reduction.

\section{References}

Alfafara, C.G., Migo, V.P., Amarante, J.A., Dallo, R.F. and Matsumura, M. (2000) Ozone treatment of distillery of slop waste., Wat. Sci and Tech., Vol.42, No.3-4, 193-198.

APHA. (1998) Standard Methods for the Examination of Water and Wastewater, $20^{\text {th }}$ edn, American Public Health Association, Washington.

Beltran, F.J., Garcia-Araya, J.F. and Acedo, B. (1994) Advanced oxidation of atrazine in water-Part I., Water. Res., Vol.28, No.10, 2153-2164.

Buschmann, H.J. and Schollmeyer, E. (1997) Ion-selective dyes for the complexation of alkali and alkaline earth cations., Supramol. Chem., Vol 8, No. 4, 385-388.

Correia, V.M., Stephenson, T., and Judd, S.J. (1994) Characterization of textile wastewater-a review., Environ. Tech. Vol.15, 917-929.

Gilbert E. (1982) Ozonation of aromatic compounds pH-dependence., Wat. Sci and Tech., Vol 14, 849-861.

Glaze, W.H., Kang, J.W. and Chapin, D.H. (1987) The chemistry of water treatment processes involving ozone, hydrogen peroxide and ultraviolet radiation., Ozo. Sci and Engg., Vol. 9, 335-352.

Juang, R.S., Tseng, R.L., Wu, F.C. and Lee, S.H. (1997) Adsorption behavior of reactive dyes from aqueous solution on chitosan., J. Chem. Tech and Biotech., Vol. 70, No.4, 391-399.

Nansheng, D., Feng, W., Fan, L. and Zan, L. (1997) Photo degradation of dyes in aqueous solutions containing Fe (III) oxalate complexes., Chemosphere., Vol.35, No. 11, 2697-2706.

Peña, M., Coca, M., Gonza'lez, G., Rioja, R. and Garc1'a, M.T. (2003) Chemical oxidation of wastewater from molasses fermentation with ozone., Chemosphere., Vol.51, No. 9, 893-900.

Qian Y., Yen Y., and Zhang H. (1994) Efficacy of pre-treatment methods in the activated sludge removal of refractory compounds in coke-plant wastewater., Water. Res., 28, No.3, 701-707.

Ramasamy, R.K., Rahman, N.A. and Wang, C.S. (2003) The effect of pH on the reduction of color, COD and TOC upon ozonation of textile dye., Malaysian. J. Sci., Vol.22, 127-131. 
Salem, I.A. (2000) Kinetics of the oxidative color removal and degradation of bromophenol blue with hydrogen peroxide catalyzed by copper (II)supported alumina and zirconia., App Catal B: Env., Vol.28, No.3-4, 153162.

Saunders F., Gould J.P., and Southerland C.R. (1983) The effect of solute competition on ozonolysis of industrial dyes., Water. Res., Vol 17, No.10, 1407-1419.

Sevimli, M.F. and kinaci, C. (2002) Decolorization of textile wastewater by ozonation and Fenton's process., Wat Sci and Tech., Vol.45, No.12, 279286.

Sevimli, M.F. and Sarikaya, H.Z. (2002) Ozone treatment of textile effluents and dyes: effect of applied ozone dose, $\mathrm{pH}$ and dye concentration., J. Chem. Tech and Biotech., Vol.77, No.7, 842-850.

Shu, H.Y. and Huang, C.R. (1995) Degradation of commercial azo dyes in water using ozonation and UV enhanced ozonation process., Chemosphere, Vol.31, No.8, 3813-3825.

Staehelin, J. and Hoigne, J. (1982) Decomposition of ozone in water: rate of initiation of hydroxide ions and hydrogen peroxide., Env. Sci and Tech., Vol.16, No.10, 676-681.

$\mathrm{Wu}$, B.J., Eiteman, M.A. and Law, S. (1998) Evaluation of membrane filtration and ozonation processes for treatment of reactive dye wastewater., J. Env. Eng., Vol.124, No.3, 272-277.

$\mathrm{Wu}$, J. and Wang, T. (2001) Ozonation of aqueous azo dye in a semi batch reactor., Water. Res., Vol.35, No.4, 1093-1099. 